\title{
Cognitive metaphor in the work of L. S. Petrushevskaya
}

\begin{abstract}
Viktoria Vyacheslavovna Radchenkoi:
M. K. Ammosov North-Eastern Federal University, Republic of Sakha, Yakutsk, Russian

Federation

Oksana Vasilievna Sizykhii(i)

M. K. Ammosov North-Eastern Federal University, Republic of Sakha, Yakutsk, Russian

Federation
\end{abstract}

Anastasiya Egorovna Alekseevaiii(i)

M. K. Ammosov North-Eastern Federal University, Republic of Sakha, Yakutsk, Russian

Federation

Anna Sofronovna Starostinaiv
M. K. Ammosov North-Eastern Federal University, Republic of Sakha, Yakutsk, Russian
Federation

\begin{abstract}
The paper dwells on functioning of cognitive metaphor in the literary texts. The metaphor in literary text is the active creative mechanism. Many researches focused on the analysis of the development of metaphorical relations, images, concepts that evolve from myth to symbol. The metaphor in the literary text is not just a means of expression, but a way of thinking and knowing the world. The academic novelty of the paper consists in the study of the author's perception of reality through conceptual images that expand the boundaries of the metaphorical space of the text. The study reveals the ways cognitive metaphors function in the short stories by Lyudmila Petrushevskaya, also describing the author's individual style, the manner of understanding reality, the peculiarity of author's thought, her contribution to the development of metaphorization, and the expansion of the metaphorical space of the text. The author's interpretation of already known symbols, images, concepts is of great importance. A substantive base that forms a metaphor in the work of Petrushevskaya is also relevant, together with the factors that influence the development of metaphorical relations, those events or phenomena that are an incentive for the development of a metaphor in the writer's work. The paper identifies algorithms of metaphorical transformations, as well as metaphorical structure of cognitive metaphor, typical of author's way of thinking and individual artistic style.
\end{abstract}

\section{Keywords}

Cognitive metaphor. Conceptualization. L. S. Petrushevskaya. Literary texts. Author's individual style. 


\title{
Metáfora cognitiva no trabalho de L. S. Petrushevskaya
}

\begin{abstract}
Resumo
$\mathrm{O}$ artigo trata do funcionamento da metáfora cognitiva nos textos literários. A metáfora no texto literário é o mecanismo criativo ativo. Muitas pesquisas se concentraram na análise do desenvolvimento de relações metafóricas, imagens, conceitos que evoluem do mito para o símbolo. A metáfora no texto literário não é apenas um meio de expressão, mas uma maneira de pensar e conhecer o mundo. A novidade acadêmica do artigo consiste no estudo da percepção da realidade do autor por meio de imagens conceituais que expandem as fronteiras do espaço metafórico do texto. O estudo revela como as metáforas cognitivas funcionam nos contos de Lyudmila Petrushevskaya, descrevendo também o estilo individual da autora, a maneira de entender a realidade, a peculiaridade do pensamento dela, sua contribuição para o desenvolvimento da metaforização e a expansão do espaço metafórico do texto. A interpretação da autora de símbolos, imagens e conceitos já conhecidos é de grande importância. Uma base substantiva que forma uma metáfora no trabalho de Petrushevskaya também é relevante, juntamente com os fatores que influenciam o desenvolvimento de relações metafóricas, os eventos ou fenômenos que são um incentivo para o desenvolvimento de uma metáfora no trabalho da escritora. $O$ artigo identifica algoritmos de transformações metafóricas, bem como a estrutura metafórica da metáfora cognitiva, típica da maneira de pensar e do estilo artístico individual da autora.
\end{abstract}

\section{Palavras-chave}

Metáfora cognitiva. Conceitualização. L. S. Petrushevskaya. Textos literários. Estilo individual do autor.

\section{Metáfora cognitiva en el trabajo de L. S. Petrushevskaya}

\begin{abstract}
Resumen
El artículo aborda el funcionamiento de la metáfora cognitiva en textos literarios. La metáfora en el texto literario es el mecanismo creativo activo. Gran parte de la investigación se ha centrado en el análisis del desarrollo de relaciones metafóricas, imágenes, conceptos que evolucionan del mito al símbolo. La metáfora en el texto literario no es solo un medio de expresión, sino una forma de pensar y conocer el mundo. La novedad académica del artículo consiste en estudiar la percepción de la realidad del autor a través de imágenes conceptuales que expanden los límites del espacio metafórico del texto. El estudio revela cómo funcionan las metáforas cognitivas en los cuentos de Lyudmila Petrushevskaya, también describe el estilo individual del autor, la forma de entender la realidad, la peculiaridad del pensamiento del autor, su contribución al desarrollo de la metaforización y la expansión del espacio metafórico de texto. La interpretación del autor de símbolos, imágenes y conceptos ya conocidos es de gran importancia. Una base sustantiva que forma una metáfora en el trabajo de Petrushevskaya también es relevante, junto con los factores que influyen en el desarrollo de las relaciones metafóricas, los eventos o fenómenos que son un incentivo para el desarrollo de una metáfora en el trabajo del escritor. El artículo identifica algoritmos de transformación metafórica, así como la estructura
\end{abstract}

Educ. Form., Fortaleza, v. 6, n. 1, e3378, jan./abr. 2021

DOI: https://doi.org/10.25053/redufor.v5i15.3378

https://revistas.uece.br/index.php/redufor/index 
metafórica de la metáfora cognitiva, típica de la forma de pensar del autor y el estilo artístico individual.

\section{Palabras clave}

Metáfora cognitiva. Conceptualización. L. S. Petrushevskaya. Textos literarios. Estilo individual del autor.

\section{Introduction}

The study of cognitive metaphor in the literary texts is relevant as it implies the study of the inner world of man, the "inner space"; the author's way of thinking, his/her deep, philosophical understanding of life and human fate are manifested through metaphorical images. Cognitive metaphor acts as a way of knowing the world around us, as a specific categorization of the phenomenal reality, and certainly as a form of conceptualizing these phenomena within the author's thinking and perception. The anthropological approach to the study of metaphor fits its nature.

The purpose of this study is to consider cognitive metaphor in the works of L.S. Petrushevskaya in terms of its meaning, and as a reflection of the author's internal world and individual artistic style.

The phenomenon of metaphorical of thinking interested numerous great students of language and philosophy, such as Aristotle, J. Ortega-y-Gasset, F. Nietzsche, E. McCormack, E. Cassirer, J. Lakoff, M. Johnson, N.D. Arutyunova, and others.

The study of cognitive metaphor in the works of J. Lakoff and M. Johnson is seminal in the field of cognitive linguistics. In Metaphors We Live By they focus attention on the ability of the metaphor to go beyond language. Indeed, the processes of human thinking themselves are metaphorical: "Our ordinary conceptual system, within which we think and act, is essentially metaphorical" (GUBAILOVSKII; LAKOFF; JOHNSON, 2008). In other words, metaphor as a phenomenon of consciousness manifests itself not only in language, but also in thinking and action. This approach makes it possible to regard metaphor as a profound and multidimensional phenomenon that embraces the interaction between language, thinking and culture.

J. Lakoff and M. Johnson note that concepts of thinking extend to all activities of the person, structure his behavior, feelings, social relations, although the conceptuality of thinking is often somewhat misunderstood by the person (GUBAILOVSKII; LAKOFF; 
JOHNSON, 2008). Thus, a cognitive metaphor having a mental nature includes a wide cognitive potential that can be used by the author of the literary text.

\section{Methodology}

The material of the study is the literary texts written by Russian author Lyudmila Petrushevskaya. Among the methods used were context and component analysis, as well as the analysis of dictionary definitions.

\section{Results and discussion}

The study identified factors affecting the metaphor formation in Petrushevskaya's works. These factors are critical situation, conflict, and drama. Conceptual images reflecting the writer's inner world have also been revealed.

The academic novelty of the paper can be explained by the insufficient number of works devoted to the study of Petrushevskaya's writing style, so the topic of the study is under-investigated. This paper first reveals and explores the metaphorical model of the author's creative thinking.

The paper is valuable from theoretical point of view, as it analyzes Petrushevskaya's individual writing style, as well as the specifics of her thinking through metaphorical images embodied in her short stories, which is important for cognitive studies in linguistics in general.

The practical significance of the work is determined by the possibility of using the results obtained as a part of courses on topical problems of cognitive linguistics, history of Russian literature and culture, as well as courses on intercultural communication related to the study of the specific nature of the mentality and culture of the Russian people.

Firstly, the task was set to consider the conceptual nature of the methaphorics in Petrushevskaya's thought, which is pronounced in her works, where cognitive metaphors often act as concepts. The conceptual images in Petrushevskaya's short stories were found and noted. The conceptual metaphor can be defined, according to Zoltán Kövecses (2018), as follows: "A conceptual metaphor is a systematic set of correspondences, or mappings, between two domains of experience". Some authors consider that "[...] as 
lexical meaning is essentially conceptual, it is natural to maintain that metaphors are also conceptual" (SVANLUND, 2007).

It can be assumed that the conceptual metaphor in Petrushevskaya's short stories arises in an undisturbed system of values, having a metaphysical paradigm as its basis, and conveying not rational but emotional transformation of modern man. The conceptual nature of the images functioning in the Petrushevskaya's texts is usually ontological. The author uses the images to reveal ideas about the existence of the world, expressing her personal perception and mindset, paying special attention to the metaphysical aspect of being.

The idea of the ontological metaphor mechanism belongs to Paul C. Martin (2013), who emphasized that "[...] the metaphor builds our conceptual operations and therefore views on the world through partial mapping of knowledge across ontological fields, generally from specific to abstract". The same opinion is expressed by I. V. Novitskaya (2019), as in her research "[...] the metaphor is given the status of a conceptual mechanism, a thinking pattern that allows projecting specific phenomena and actions onto a wider range of abstract ones".

The metaphysical contents of Petrushevskaya's literary texts is logical from the point of view of her "metaphysical style", namely her special attitude to language units and language means. V. V. Vinogradov (1941), exploring the non-hierarchical experiments of Mikhail Lermontov, reveals their connection with the traditions of "poetry prose", which was developing on the basis of poem style, and points out the proximity of the writer's works to those of Bestuzhev-Marlinsky and Gogol. The ambivalent nature of the linguistic composition, including, on the one hand, lyrical and poetic vocabulary, and, on the other hand, according to Pushkin, "chatter", can be explained by the Lermontov's worldview, his position as the author of the verbal canvas. V. V. Vinogradov (1941) here refers to B.M. Eichenbaum.

The dialogue between Petrushevskaya's prose and Russian Romatic tradition was pinpointed by T. G. Prokhorova (2008): "In the short stories [...] one can see a Romantic discourse as a manifestation of the author's outlook, her understanding of the world, her idea of the value balance between moment and eternity". In other words, author's simulation of reality reveals metaphysical nature.

Educ. Form., Fortaleza, v. 6, n. 1, e3378, jan./abr. 2021

DOI: https://doi.org/10.25053/redufor.v5i15.3378

https://revistas.uece.br/index.php/redufor/index 
In the case of Lyudmila Petrushevskaya, the unexpected turn is an oxymoronic component of the metaphor "black butterfly" that implies the antinomy of metaphysical categories of "birth" and "death", which reflect the biography of the main character. In this case, the source of metaphorization is the situation unfolding in the story, and the purpose is the character's understanding of the situation. The oxymoronic nature of "birth" and "death" concepts is a special manifestation of author's complex perception of reality, a manifestation of her non-standard philosophical thinking and individual writing style. It should be noted that Petrushevskaya's creativity, her worldview and perception include those specific concepts that are being born in critical situations of conflict and drama.

Petrushevskaya's conceptual images are heterogeneous, contradictory, while their internal components are often inconsistent. Kimmel (2010) emphasizes this kind of ambiguity, saying also that:

[...] conceptual metaphors are the cohering device par excellence. While conceptual metaphors may create 'internal binding' in ontologically coherent clusters, complementary 'external binding' models are necessary to explain the mixed clusters (and ultimately for a full explanation of all kinds of metaphor-based argumentation).

However, according to Corts and Meyers (2002), "[...] clusters largely include a central root metaphor". In the center of Petrushevskaya's attention in the short story "Black Butterfly" there is an archaic legend about the soul of a shaman. Shamanism becomes a metaphysical objectification of the narrative, assigning certain omplications to the story, including the phrase "black butterfly" as a mythological marker. The archaic invariant of the butterfly myth refers to the legend of the Great Goddess, or the Great Mother. The image of the Great Goddess dates back to the Paleolithic age, when the Great Mother was considered the supreme deity, representing both heaven and earth, life and death. One of the insects representing the goddess was a butterfly. Hence the belief that witches can turn into butterflies, that butterflies are related to conception, presage war, or are the souls of the dead (BUTTERFLY, n.d.). However, the formation of a conceptual metaphor can be regarded as a result of conceptual integration as well. The researchers note that "[...] the result of conceptual integration is generated by exchange processes between at least two interacting semantic domains" (WISHMANN, 2019). Novitskaya (2019) also notes that "[...] unlike the model of conceptual metaphor wherein 
two spaces (source and purpose) interact, the metaphor in terms of integration theory is multi-space".

In "Impulse", another short story, the leading conceptual metaphor is also shaped by a dramatic situation. The main character, who saw her husband with the mistress, feels disgusted, and "driven by impulse" runs away from her own apartment. Man's treason is conceptualized as a special emotion of physical desire, but acquires the characteristics of a suffering subject, a deceived woman. As the story unfolds, the metaphor of "impulse" appears, connecting metaphysical betrayal and loyalty (the husband is also "driven by impulse", so he takes his wife to their country-house for reconciliation).

At the heart of the plot's organization of the short story "Stay for a moment" is also the opposition "friend or foe" or "home or temporary shelter", which forms the concept of "moment". The main character Tatyana K., having lost her job, founds herself as a guest in the country-house of her friend Sonya. The author's idea of the time that can be subjected to external influence, is represented in the conceptual metaphor of "moment" that represents both the temporary state of affairs and the eternity.

In this short story the role of the mythological plan of the conceptual metaphor of "moment" is played by a clear literary allusion. Petrushevskaya transforms the famous phrase from Goethe's Faust ("Stay a while, you are so beautiful!"). It is not so much about good and evil or the highest degree of pleasure as about the so-called emotional intelligence and the fleeting state of happiness.

The metaphysical beginning, which can be seen in the realities of the world, is a necessary component of the author's perception of art: "[...] there is a sheet of paper or canvas milled with a brush ... We were given a sign on this paper, we understood it and felt something. A conditional sign, a signal" (PETRUSHEVSKAYA, 2003). The writer emphasizes the deep ontological basis of the creative image. This statement reminds of art's transcendental nature.

It is possible to understand the fact underlying the picture seriously, as the museum guides do ... in fact Ivan the Terrible, killing his son, for example, it is an absolutely flat canvas and no Ivan is on it, i.e. it is all a game of light. There's a canvas or cardboard, and there's paint on it, that's what it's like. As in a terrible story, there is no horror. There's only paper and beech. There was not what was described! Everything is composed! This is not newspaper information ... Where does darkness or light come from? Where does sadness, compassion, fear, joy

Educ. Form., Fortaleza, v. 6, n. 1, e3378, jan./abr. 2021

DOI: https://doi.org/10.25053/redufor.v5i15.3378

https://revistas.uece.br/index.php/redufor/index 
come from? And they are created by the reader and viewer himself, using some signs that are clear to him [...]. And a man understands signs. And identification of these signs, most often, is the result of some gradual movement. (PETRUSHEVSKAYA, 2003).

In many ways these reflections on the artistic language resonate with the ideas of the philosopher Merab Mamardashvili (1990):

[...] consciousness is a very strange phenomenon, which is present and which at the same time cannot be seized, imagined as a thing, that is, it is impossible to build a theory of it. Neither in the form of a prior philosophical concept, nor in the form of a real phenomenon described by psychological and other means, consciousness cannot be theorized, objectified.

This position is in line with Petrushevskaya's (n.d.) worldview, on which the writer insists in one of her rare interviews. The composition of Petrushevskaya's short story, which is based on the replay, introduces a specific interchange between the beginning and the end of the text. The special meaning of the composition is related to the disclosure of the idea of human consciousness. Reflecting on the philosophy of Kant, Mamardashvili (1990) said: "[...] human in man is not reduced to its purely natural properties"; the thinker speaks about the complex processes that occur in the consciousness of Homo Sapiens.

The text is built as a story about the butterfly and about the attempts to get rid of it. Starting with "In summer, a black butterfly flew into the window of Nika's room. It was late evening, her son was away with a friend. The butterfly, attracted by light, spun for a long time at the lamp shade, and then disappeared" towards "Then Nika very carefully, having put a powered-on luminous flashlight on the floor in the bathroom, raked up a butterfly with a napkin, covered it with her palm and, coming out on the balcony, released this lost soul to its freedom" (PETRUSHEVSKAYA, 2008). The stories of heroes, with a butterfly in the center, are woven into the narrative. The composition of the story represents a system of relations: shamanism - mundanity, children - parents, man world, indifference - kindness. The meaning function of the composite form changes the status of the event, the butterfly in Nika's apartment from random and unexpected to natural. The butterfly flight chimes with the situations that Nika, Yelena, Erik, and Kim line through. Nika's spiritual crisis is in the center. The most important structural principle is the repetition, as if reproducing the trajectory of the butterfly. The contrast between the shaman butterfly and the summer evening butterfly, expands the meaningful capabilities

Educ. Form., Fortaleza, v. 6, n. 1, e3378, jan./abr. 2021

DOI: https://doi.org/10.25053/redufor.v5i15.3378

https://revistas.uece.br/index.php/redufor/index 
of the metaphor, expanding the semantic perspective. Contrast is a principle of vitality that balances rational and emotional, i.e. performs a harmonizing function. For the first time, Nika learned about butterfly's soul from the story told by Eric. The image of the butterfly restores the integrity of Nika's being, her inner world. The stable imagemetaphor "black butterfly" makes it possible to understand the problem of human perception of reality in its relation to the "natural order of the world" - Mamardashvili's (1990) wording.

The contrast also performs a characteristic function, as heroes are placed in different coordinate systems of life. The contrast allows showing their life aspirations and assessing them. This reception brings the reader to understand the idea of the original basis of being, the spirit as the form of a living body. Contrast functioning like that can be found in other Petrushevskaya's short stories, such as "The Dance of Death", "Eyes", and "The Doll". In the last short story, the conceptual metaphor of crying is presented in two final sentences: "He walked and cried, remembering his mother. There was a non-young man, crying about himself'. Crying is both a person's tears of memory and the outcome of a meaningless life.

Mamardashvili (1990) notes that the search itself for the original, from which one could draw a person, consciousness and meaning, is futile, as it leads to the bad infinity. The real problem is to try to find out how a person exercises himself as a thinking creature "here and now", how he is able to "keep" himself in this state, because physical mechanisms do not provide for this (MAMARDASHVILI, 1990).

Petrushevskaya differentiates between "the sense of reality" and "the reality itself". The main thing in her perception is not the fact itself, but the impression:

\footnotetext{
'When I see Falk's graphics, I am physically hot in the upper respiratory tract, if I may say so, from some unimaginable happiness. Just holding my hand under my throat, as I repeatedly noticed'. The fact may be very different - a house in the village among the trees, the bridges of Paris at sunset. The works of Mavrina from the group '13' times cause the same sensation. And there's just paper and a portrait on it, and a rather ugly elderly woman, often naked. Or Falk, a bridge across the River Seine, and there's something with a chimney on the other side, maybe a factory. But there's nothing there, either a piece of paper or a canvas grinded with a brush. It was raw, then dried. And I stand in front of it and squint like a cat in the sun, with warmth and happiness. And in a piece of paper covered with lines of signs, what is it? And there's a poem 'A flying ridge of clouds becomes thinner'. We were given a sign on this paper, we understood it and felt something. A conditional sign, a signal. It has nothing to do with the fact. A factory
}

Educ. Form., Fortaleza, v. 6, n. 1, e3378, jan./abr. 2021

DOI: https://doi.org/10.25053/redufor.v5i15.3378

https://revistas.uece.br/index.php/redufor/index 
puffs or clouds in the sky - who cares about this? "We're happy beyond that" (PETRUSHEVSKAYA, 2003).

The language is thus represented as a creation of the spirit, and the black butterfly in the short story symbolizes the blurred line between worlds that Nika tries to find in order to see the real life. Embracing the surreal into one's earthly life is a condition for identifying Nika in the world, otherwise staying on a woman's sinful land is imaginary. Each of the heroes of the stories "Remained There", "The Citadel", "Ripples on Water" make sense of reality in their own way, individually, personally, which is noted in portrait characteristics of heroes: "non-closing eyes", "huge eyes", "heavy eyes", "blindness test", and more. The earthly nature of the characters is revealed by the conceptual metaphor of "the eye".

The artist tries to find his own language to understand what is happening, and this language is different from the imagery language of other writers. The fact that is depicted in a similar way has no meaning. So the artist puts in a good deal of effort to invent his own language and to express something beyond what is depicted, perhaps something essentially unlike reality (PETRUSHEVSKAYA, 2003). In Petrushevskaya's short story we see a discrepancy between the author's perception of the world and the phenomena that occur in the daily life of a reader, which makes the complexity of literary images interesting for examination. Arguably the metaphorical image of a black butterfly provides a kind of philosophical context in which several literary works show up, such as Bradbury's "A Sound of Thunder", Asimov's "The End of Eternity", and Grimm brothers' fairy-tale "The Louse and the Flea". The common feature is the so-called butterfly effect (a concept introduced by Edward Norton Lorenz (BUTTERFLY, n.d.), which is a change in space and time associated with small effects compared to a wave of butterfly wings. For example, it is impossible to predict how the murder of the little, "iridescent green, gold, and black" graceful creature will affect further life. Life is, according to Bradbury (n.d.), a "complete mystery".

The butterfly proves to be a significant image for Petrushevskaya, as well as for Joseph Brodsky, whose poetry is distinguished by its metaphysical style. As I. A. Snegiryov points out, "the concept of 'metaphysicist poet' has emerged relatively recently, and is still used somewhat confusingly". According to Kreps, "[...] a metaphysicist poet is in Russian is synonymous for the poet-philosopher" (SNEGIRYOV, 2012). While 
Shaitanov (1998) assumes that "[...] metaphysical poetry is a predominantly linguistic and stylistic phenomenon by its origin and by its essence". In 1972, a thirty-two-year-old Brodsky wrote: poem "Butterfly". In his Baroque poem he describes a butterfly, which absorbs the diversity of existence.

In the plot, the metaphor of the dead soul takes life beyond its usual limits. The opposition between the sacred (the soul of a shaman) and the secular (the desire to see the insect as a sacred sign) demonstrates the existence of two interconnected and independent spheres of life. Their correlation with the heroine generates a metaphysical plane of the story.

The antinomy of the sacred and the secular reveals metaphysical universals of birth and death. Life as a permanent essence is timeless. By trusting Erik's shamanic abilities that he inherited from his mother, Nika overcomes the meaninglessness of her own existence. By saving her son from false danger, she endows her life with meaning. Belief in the irrational (shamanism) and illusory (materialization of the soul) is a necessary condition for rendering the life of the disappointed person meaningful, as it saves her from loneliness and madness in the context of the sacrificial love for children. Thus, the story represents a modern original version of the spiritual resurrection, which consists of the following elements:

1. Searching for faith;

2. Regaining the lost spiritual harmony (family relations). Nika regards Erik, as compared to her son Kim, as a saint: "This man, Erik, was really a kind of a saint in his influence on those around him. Everyone wanted to be near him, as he bestowed peace on people with his chastity and kindness" (PETRUSHEVSKAYA, 2008);

3. Overcoming loneliness.

Resurrection is understood as a replacement for the selfish (consumerist) personal psychology by the spiritual psychology. Nika's thinking undergoes changes. It is about the life and death of the spiritual self of a person. The dominance of the butterfly image in the storyline emphasizes the notion of eternal life by illustrating its power. We are by no means implying the Orthodox Christian vision of resurrection. In the miracles of shamanism, Nika seeks to find an explanation for her own experiences, for her troubled relationship with the son and her disorderly personal life. Renouncing 
herself and her personal happiness, Nika opens her heart to her son and submits her life to him. All physical things seem rough and coarse to her. So she turns to Yelena, to interesting and thoughtful conversations about Shakespeare and literature, longing for Erik's stories about the soul and shamanism. The ethereal subtle quality of being is a lifesaving refuge for the heroine. The literal plan of the resurrection is to discover the hidden possibilities of the human being. The idea of the unity of heaven and earth is the idea of universal harmony.

\section{Conclusion}

Thus, it can be concluded that the forming context for the conceptual metaphors in Petrushevskaya's short stories is usually a critical situation, a conflict or a drama. At the same time, the following structure of cognitive metaphor formation is revealed: the source is the story told by the main character, and the goal is the understanding of the story by characters included in the plot. Cognitive metaphor in Petrushevskaya's creative work is a concept that reveals author's questions and reflections about human being, which are accordingly ontological.

Indeed, the multi-faceted interpretations of conceptual images in Petrushevskaya's work, together with the metaphorical projection of the structural and semantic plan, significantly expand the framework of the metaphorical space of literary text, as well as the range of philosophical understanding of reality, confirming the idea that the metaphor phenomenon is a succinct concept that should be considered not only from the point of view of linguistics and literary studies, but also of philosophy, psychology and cultural studies.

\section{References}

BRADBURY, R. And shook the thunder. Retrieved from: http://raybradbury.ru/library/story/52/8/1/

BUTTERFLY EFFECT. Retrieved from: https://vikent.ru/author/2059/

BUTTERFLY. Retrieved from: http://www.newacropol.ru/alexandria/symbols/buterfly 
CONCHETTO, S. D. Problem of Interpretation of Literary Images in Fine Art. Institute painting, sculpture and architecture, 1989.

CORTS, D. P.; MEYERS, K. Conceptual clusters in figurative language production. Journal of Psycholinguistic Research, v. 31, n. 4, p. 391-408, 2002.

GUBAILOVSKII, V.; LAKOFF, G.; JOHNSON, M. Metaphors, we live by. Novyi Mir, v. 10, p. 188-189, 2008.

KIMMEL, M. Why we mix metaphors (and mix them well): Discourse coherence, conceptual metaphor, and beyond. Journal of Pragmatics, v. 42, n. 1, p. 97-115, 2010.

KÖVECSES, Z. Metaphor in media language and cognition: a perspective from conceptual metaphor theory. Lege artis-language yesterday today tomorrow, v. 3, n. 1, p. 124-141, 2018.

MAMARDASHVILI, M. K. Consciousness as a philosophical problem. Questions of Philosophy, v. 10, p. 3-18, 1990.

MARTIN, P. C. The exploratory and reflective domain of metaphor in the comparison of religions. Zygon, v. 48, p. 936-965, 2013.

NOVITSKAYA, I. V. The conceptual metaphor theory and the development of alternative theories within the cognitive approach to metaphor (a review of European and American metaphor studies). Yazyk i kultura-language and culture, v. 46, p. 76-101, 2019.

PETRUSHEVSKAYA, L. S. Black Butterfly. SPb: Amphora, 2008.

PETRUSHEVSKAYA, L. S. Lecture about genres, v. 9. Moscow, 2003.

PETRUSHEVSKAYA, L. S. Snob. Retrieved from: http://www.snob.ru/profile/5286

PROKHOROVA, T. G. Prose by L. Petrushevskaya as a system of discourse: abstract thesis dr.s philological sciences. Kazan, 2008.

RUBTSOVA, G. V. Brief Literary Encyclopedia, Soviet encyclopedia, 1962-1968. Moscow, 1968. v. 3.

SHAITANOV, I. O. Equation with two unknown. Literature Issues, v. 6, p. 19-29, 1998.

SNEGIRYOV, I. A. Metaphysical style in poetry of Joseph Brodsky, abstract thesis cand. philological sciences. Vladimir, 2012.

SVANLUND, J. Metaphor and convention. Cognitive Linguistics, v. 18, n. 1, p. 47-89, 2007. 
VINOGRADOV, V. V. Style of Lermontov prose. Moscow: Russian Academy of Sciences of the USSR, 1941. v. 1.

WISCHMANN, A. Research in Conceptual-integration as a stimulus for self-reflection in comparative literary studies?. Lili-Zeitschrift fur Literaturwissenschaft und Linguistik, v. 49, n. 3 , p. $517-537,2019$.

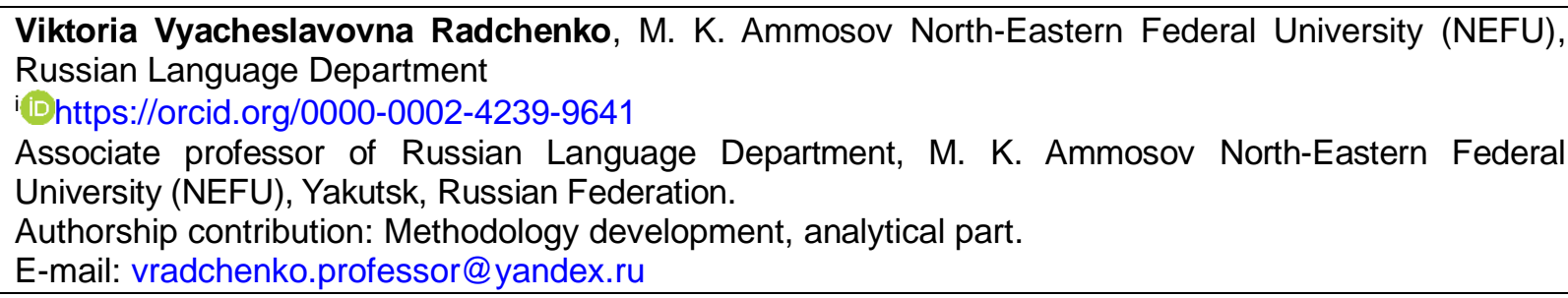

Oksana Vasilievna Sizykh, M. K. Ammosov North-Eastern Federal University (NEFU), Russian and Foreign Literature Department

ii@ilttps://orcid.org/0000-0001-9716-1457

Associate professor of Russian and foreign literature Department, M. K. Ammosov North-Eastern Federal University (NEFU), Yakutsk, Russian Federation.

Authorship contribution: Methodology development, analytical part.

E-mail: oksana.sizykh@bk.ru

Anastasiya Egorovna Alekseeva, M. K. Ammosov North-Eastern Federal University (NEFU), Russian Language Department

iii Dhttps://orcid.org/0000-0002-7228-2663

Assistant professor of Russian Language Department, M. K. Ammosov North-Eastern Federal University (NEFU), Yakutsk, Russian Federation.

Authorship contribution: Review of theoretical base.

E-mail: anastasiyalekseeva@bk.ru

Anna Sofronovna Starostina, M. K. Ammosov North-Eastern Federal University (NEFU), Russian Language Department

iv (D.Dttps://orcid.org/0000-0002-0011-9541

Assistant professor of Russian Language Department, M. K. Ammosov North-Eastern Federal University (NEFU), Yakutsk, Russian Federation.

Authorship contribution: Review of theoretical base.

E-mail: anneta-starostina@bk.ru

Responsible publisher: Lia Machado Fiuza Fialho Ad hoc experts: Karla Nascimento and Cristine Brandenburg

Educ. Form., Fortaleza, v. 6, n. 1, e3378, jan./abr. 2021

DOI: https://doi.org/10.25053/redufor.v5i15.3378

https://revistas.uece.br/index.php/redufor/index 


\section{How to cite this article (ABNT):}

RADCHENKO, Viktoria Vyacheslavovna et al. Cognitive metaphor in the work of L. S. Petrushevskaya. Educ. Form., Fortaleza, v. 6, n. 1, e3378, 2020. Retrieved from: https://revistas.uece.br/index.php/redufor/article/view/3378

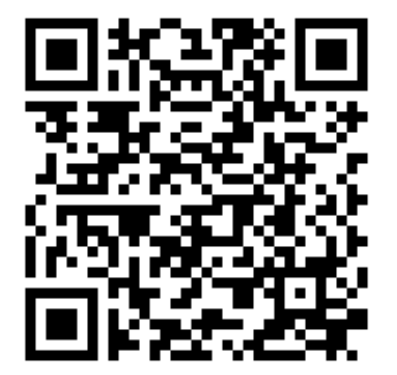

Received on July 10, 2020.

Accepted on August 4, 2020.

Published on September 24, 2020. 